\title{
NEONATAL AND MATERNAL SERUM TRANSAMINASE ACTIVITY AT BIRTH
}

\author{
BY
}

\author{
I. KESSEL and W. M. POLITZER \\ From the Department of Paediatrics, University of the Witwatersrand and the Queen Victoria Maternity \\ Hospital, Johannesburg and South African Institute for Medical Research, Johannesburg, South Africa
}

(RECEIVED FOR PUBLICATION AUGUST 8, 1960)

Serum transaminase studies in adults have been widely covered in the medical literature and variations in their activity are well established in medicine particularly in relation to heart, liver and skeletal muscle disease. Wróblewski (1959) stressed the value as a diagnostic aid of increased transaminase activity when correlated with the clinical pattern. Kove, Goldstein and Wróblewski (1957 a, b) also studied the serum glutamic-oxalacetic transaminase (GOT) activity in the neonatal period. These workers estimated the serum GOT activity in 63 normal full-term newborn infants up to 11 days after birth and included nine cord blood estimations; this study of Kove et al. (1957 a, b) showed a wider physiological range than found in normal adults and recorded a normal range in the newborn period from 13 to 105 units with the exception of one infant in whom a level of 160 units was recorded. The cord blood estimations showed a lower range of GOT activity than in the older neonatal cases studied. The same workers in a further study estimated the activity of serum glutamic-pyruvic transaminase (GPT) in 63 newborn infants in the first week after birth and considered values up to 90 units as being normal in this age group. In this series nine cord blood estimations were also included and these showed levels varying from 12 to 40 units. Knutson, Cornatzer, Moore and Nelson (1958) studied GOT activity during pregnancy and found that normal pregnancy did not appear to influence the activity level.

The study being presented in this paper is a further attempt to establish physiological limits of serum GOT and GPT activity in mothers and their newly-born infants. Cord blood specimens were studied and the maternal blood samples were taken at the time of delivery. This study was done on a series of 19 European and 26 Bantu cases. Tables 1 and 2 record the findings in these groups; they include the maternal age and parity and the infants' birth weight and sex in addition to the serum GOT and GPT activity levels. The method of estimating the levels of enzyme activity was that described by King (1958).

The 19 European cases included 11 first pregnancies, six mothers with one previous child, and two having had three and four previous pregnancies. There were nine females and 10 males in this series and one premature infant weighing $4 \mathrm{lb} .13 \mathrm{oz}$. was included.

In the 19 European cases as listed in Table 1, 16 showed the serum GOT values to be consistently higher in the cord bloods of the infants than in their mothers at birth. Fourteen of the cord blood values were above the normal upper limits indicated by Kove and his colleagues and in eight of the mothers their values were above the generally accepted normal values.

The serum GPT activity ranges in cord blood were all, with the exception of two cases, below the normal upper limit level of 90 units suggested by Kove and his colleagues; our study recorded a range of 10 to 61 units with the exception of the two cases of 116 and 102 units, both in male infants. The maternal range of serum GPT activity was from 10 to 98 units with a single exception of 134 units.

The 26 Bantu cases studied included eight first pregnancies, nine with one previous pregnancy and the remainder with two and three previous pregnancies; the series included 16 male and 10 female infants with birth weights ranging from $5 \mathrm{lb} .3 \mathrm{oz}$. to $9 \frac{1}{2} \mathrm{lb}$.

These cases showed 11 cord blood GOT values above the levels of activity suggested by Kove et al.; the range in the whole series varied from 35 to 190 units. The mothers' levels were all 100 units or less with four exceptions. The GPT levels in the cord blood studies in this group ranged from 15 to 78 units and the mothers from 10 to 75 units with one exception of 118 units.

In both groups studied there were many fairly high GOT levels in cord blood specimens above 
TABLE 1

SERUM GOT AND GPT ACTIVITY LEVELS IN 19 EUROPEAN MOTHERS AND THEIR NEWLY-BORN INFANT'S CORD BLOOD

\begin{tabular}{|c|c|c|c|c|c|c|c|c|}
\hline $\begin{array}{c}\text { European } \\
\text { Cases }\end{array}$ & $\begin{array}{c}\text { Maternal } \\
\text { Age } \\
\text { (years) }\end{array}$ & Parity & $\begin{array}{c}\text { Birth } \\
\text { Weight } \\
\text { (lb. oz.) }\end{array}$ & $\begin{array}{c}\text { Sex } \\
\text { of } \\
\text { Infant }\end{array}$ & $\begin{array}{c}\text { Maternal } \\
\text { Serum GOT } \\
\text { Units/100 ml. }\end{array}$ & $\begin{array}{c}\text { Infant } \\
\text { Serum GOT } \\
\text { Units } / 100 \mathrm{ml} .\end{array}$ & $\begin{array}{c}\text { Maternal } \\
\text { Serum GPT } \\
\text { Units } / 100 \mathrm{ml} .\end{array}$ & $\begin{array}{c}\text { Infant } \\
\text { Serum GPT } \\
\text { Units } / 100 \mathrm{ml} .\end{array}$ \\
\hline $\begin{array}{r}1 \\
2 \\
3 \\
4 \\
5 \\
6 \\
7 \\
8 \\
9 \\
10 \\
11 \\
12 \\
13 \\
14 \\
15 \\
16 \\
17 \\
18 \\
19\end{array}$ & $\begin{array}{l}18 \\
38 \\
26 \\
20 \\
20 \\
24 \\
17 \\
20 \\
22 \\
21 \\
28 \\
18 \\
27 \\
21 \\
20 \\
37 \\
23 \\
27 \\
21\end{array}$ & $\begin{array}{c}\text { Primip } \\
3 \\
\text { Primip } \\
\text { Primip } \\
\text { Primip } \\
1 \\
\text { Primip } \\
\text { Primip } \\
\text { Primip } \\
1 \\
1 \\
\text { Primip } \\
1 \\
1 \\
\text { Primip } \\
4 \\
\text { Primip } \\
1 \\
\text { Primip }\end{array}$ & $\begin{array}{cc}7 & 7 \\
6 & 8 \frac{1}{2} \\
8 & 2 \\
7 & 6 \frac{1}{2} \\
6 & 10 \\
9 & 13 \frac{1}{2} \\
4 & 13 \\
7 & 6 \frac{1}{2} \\
6 & 12 \frac{1}{2} \\
6 & 14 \frac{3}{4} \\
7 & 7 \frac{1}{2} \\
6 & 4 \\
6 & 11 \frac{1}{2} \\
8 & 6 \\
7 & 14 \frac{1}{2} \\
6 & 14 \\
6 & 9 \frac{1}{2} \\
6 & 15 \\
7 & 5 \frac{1}{2}\end{array}$ & $\begin{array}{l}\mathbf{F} \\
\mathbf{M} \\
\mathbf{F} \\
\mathbf{M} \\
\mathbf{F} \\
\mathbf{F} \\
\mathbf{F} \\
\mathbf{M} \\
\mathbf{M} \\
\mathbf{F} \\
\mathbf{F} \\
\mathbf{M} \\
\mathbf{F} \\
\mathbf{M} \\
\mathbf{M} \\
\mathbf{M} \\
\mathbf{F} \\
\mathbf{M} \\
\mathbf{M}\end{array}$ & $\begin{array}{r}60 \\
95 \\
98 \\
119 \\
255 \\
40 \\
106 \\
119 \\
60 \\
146 \\
80 \\
39 \\
64 \\
60 \\
160 \\
60 \\
60 \\
131 \\
130\end{array}$ & $\begin{array}{r}110 \\
202 \\
150 \\
185 \\
190 \\
139 \\
80 \\
185 \\
140 \\
148 \\
90 \\
205 \\
110 \\
83 \\
133 \\
80 \\
105 \\
170 \\
187\end{array}$ & $\begin{array}{r}30 \\
17 \\
15 \\
98 \\
10 \\
40 \\
11 \\
98 \\
27 \\
38 \\
30 \\
26 \\
50 \\
58 \\
134 \\
50 \\
50 \\
60 \\
20\end{array}$ & $\begin{array}{r}35 \\
116 \\
10 \\
47 \\
30 \\
61 \\
29 \\
47 \\
28 \\
40 \\
58 \\
28 \\
50 \\
60 \\
34 \\
20 \\
46 \\
102 \\
20\end{array}$ \\
\hline
\end{tabular}

TABLE 2

SERUM GOT AND GPT ACTIVITY LEVELS IN 26 BANTU MOTHERS AND THEIR NEWLY-BORN INFANT'S CORD BLOOD

\begin{tabular}{|c|c|c|c|c|c|c|c|c|}
\hline $\begin{array}{c}\text { Bantu } \\
\text { Cases }\end{array}$ & $\begin{array}{c}\text { Maternal } \\
\text { Age } \\
\text { (years) }\end{array}$ & Parity & $\begin{array}{c}\text { Birth } \\
\text { Weight } \\
\text { (lb. oz.) }\end{array}$ & $\begin{array}{c}\text { Sex } \\
\text { of } \\
\text { Infant }\end{array}$ & $\begin{array}{c}\text { Maternal } \\
\text { Serum GOT } \\
\text { Units/100 ml. }\end{array}$ & $\begin{array}{c}\text { Infant } \\
\text { Serum GOT } \\
\text { Units/100 ml. }\end{array}$ & $\begin{array}{l}\text { Maternal } \\
\text { Serum GPT } \\
\text { Units } / 100 \mathrm{ml} .\end{array}$ & $\begin{array}{c}\text { Infant } \\
\text { Serum GPT } \\
\text { Units } / 100 \mathrm{ml} .\end{array}$ \\
\hline $\begin{array}{r}1 \\
2 \\
3 \\
4 \\
5 \\
6 \\
7 \\
8 \\
9 \\
10 \\
11 \\
12 \\
13 \\
14 \\
15 \\
16 \\
17 \\
18 \\
19 \\
20 \\
21 \\
22 \\
23 \\
24 \\
25 \\
26\end{array}$ & $\begin{array}{l}24 \\
27 \\
23 \\
24 \\
26 \\
18 \\
19 \\
22 \\
27 \\
25 \\
20 \\
15 \\
23 \\
22 \\
26 \\
19 \\
26 \\
23 \\
20 \\
20 \\
19 \\
29 \\
29 \\
18 \\
18 \\
26\end{array}$ & $\begin{array}{c}2 \\
\text { Primip } \\
\text { Primip } \\
1 \\
3 \\
\text { Primip } \\
1 \\
1 \\
3 \\
2 \\
1 \\
\text { Primip } \\
3 \\
1 \\
2 \\
\text { Primip } \\
3 \\
1 \\
1 \\
2 \\
\text { Primip } \\
2 \\
1 \\
\text { Primip } \\
\text { Primip } \\
1\end{array}$ & $\begin{array}{cc}7 & 4 \frac{1}{2} \\
7 & 13 \frac{1}{2} \\
5 & 15 \frac{1}{2} \\
7 & 6 \\
8 & 8 \\
5 & 3 \\
7 & 13 \\
6 & 9 \\
7 & 9 \\
5 & 13 \frac{1}{2} \\
6 & 8 \\
9 & 8 \\
8 & 2 \frac{1}{2} \\
8 & 8 \\
5 & 13 \\
6 & 5 \frac{1}{2} \\
5 & 12 \\
8 & 2 \\
6 & 1 \\
7 & 4 \\
8 & 2 \\
7 & 8 \\
8 & 2 \\
6 & 7 \\
6 & 7 \\
6 & 12\end{array}$ & $\begin{array}{l}\mathbf{M} \\
\mathbf{M} \\
\mathbf{F} \\
\mathbf{M} \\
\mathbf{M} \\
\mathbf{F} \\
\mathbf{F} \\
\mathbf{M} \\
\mathbf{M} \\
\mathbf{F} \\
\mathbf{F} \\
\mathbf{M} \\
\mathbf{M} \\
\mathbf{F} \\
\mathbf{F} \\
\mathbf{M} \\
\mathbf{F} \\
\mathbf{M} \\
\mathbf{F} \\
\mathbf{M} \\
\mathbf{M} \\
\mathbf{M} \\
\mathbf{F} \\
\mathbf{M} \\
\mathbf{M} \\
\mathbf{M}\end{array}$ & $\begin{array}{r}40 \\
80 \\
75 \\
80 \\
120 \\
82 \\
140 \\
40 \\
85 \\
70 \\
150 \\
42 \\
75 \\
130 \\
90 \\
78 \\
100 \\
80 \\
80 \\
75 \\
85 \\
65 \\
70 \\
75 \\
70 \\
75\end{array}$ & $\begin{array}{r}80 \\
85 \\
100 \\
190 \\
100 \\
130 \\
165 \\
100 \\
120 \\
110 \\
90 \\
70 \\
115 \\
35 \\
180 \\
128 \\
90 \\
90 \\
90 \\
90 \\
165 \\
132 \\
105 \\
165 \\
70 \\
100\end{array}$ & $\begin{array}{r}10 \\
30 \\
18 \\
25 \\
65 \\
29 \\
40 \\
35 \\
40 \\
20 \\
25 \\
15 \\
32 \\
30 \\
23 \\
28 \\
40 \\
50 \\
75 \\
118 \\
24 \\
23 \\
30 \\
16 \\
35 \\
25\end{array}$ & $\begin{array}{l}20 \\
30 \\
45 \\
72 \\
18 \\
28 \\
30 \\
40 \\
20 \\
30 \\
40 \\
25 \\
20 \\
50 \\
55 \\
52 \\
20 \\
65 \\
78 \\
30 \\
25 \\
35 \\
30 \\
30 \\
15 \\
30\end{array}$ \\
\hline
\end{tabular}

the suggested upper limit of normal; it is suggested by this study on normal infants that they may show higher GOT values on cord blood specimens than previously accepted.

\section{Summary}

A study is presented of serum GOT and GPT activity in the cord blood of normal newborn European and Bantu infants and their mothers at the time of birth; the ranges of activity varied between the limits as recorded in the accompanying Tables and showed a higher range of GOT activity in cord blood samples of normal newborn infants than previously recorded.

The authors wish to acknowledge their gratitude to Professor O. S. Heyns, Drs. J. H. S. Gear, F. Daubenton, L. G. R. van Dongen and J. M. Samson for providing facilities to undertake this study. They wish to thank the Nursing Staff of the Labour Ward, Queen Victoria Maternity Hospital and the Bridgman Memorial 
Hospital for their co-operation in the collection of blood samples and also the Staff of the Biochemistry Department, South African Institute for Medical Research, for their technical assistance.

\section{RFFERENCES}

King, J. (1958). Routine methods for the estimation of serum transaminase. J. med. Lab. Technol., 15, 17.
Knutson, R. G., Cornatzer, W. E., Moore, J. H. and Nelson, W. W. (1958). Serum lactic dehydrogenase and glutamic oxalacetic transaminase activities in normal pregnancy. J. Lab. clin. Med., $51,773$.

Kove, S., Goldstein, S. and Wróblewski, F. (1957a). Activity of glutamic-oxaloacetic transaminase in the serum in the neonatal period. Pediatrics, 20, 584.

- (1957b). Measurement of activity of transaminases in the serum as an aid in differential diagnosis of jaundice in the neonatal period. Ibid., $20,590$.

Wróblewski, F. (1959). The clinical significance of transaminase activities of serum. Amer. J. Med., 27, 911. 